ISSN: $2036-5438$

\title{
Sub-national constitutional politics: contesting or complementing, replicating or innovating, traditional constitutionalism?
}

by

\author{
Paul Blokker and Werner Reutter*
}

\begin{abstract}
This special issue of Perspectives on Federalism collects papers mostly presented at the General Conference of the European Consortium of Political Research in September 2014. The issue contains five papers dealing with the role, the status, the dynamics, and the functions of sub-national constitutional politics and sub-national constitutionalism in a number of member states of the EU as well as in a comparative, non-EU perspective. Even though the papers take different perspectives on the topic at hand, they all engage with the contribution sub-national constitutions can make to democracy and the nationstate within as well as outside of Europe.
\end{abstract}

Key-words

Sub-national constitutionalism, comparative constitutional law, comparative federalism, European integration, developing countries 
1.

This special issue of Perspectives on Federalism tackles the question whether and in what respect sub-national constitutional politics and sub-national constitutionalism are linked to self-rule, regional democracy, and multilayered systems. We understand sub-national constitutions in a broad sense. They include constitutional law as well as sub-national legal texts that work and have similar effects as proper constitutions. In addition, we consider the constitutional "space" national constitutions grant to sub-national autonomy as well as bottom-up claims for regional autonomy in centralized states. Evidently, sub-national politics dealing with constitutions and constitutional politics in this broad sense pertains to the aforementioned questions. Yet, it is not always clear in what way and with what effect sub-national constitutions do provide answers, nor what the "right" degree of subsidiarity or sub-national autonomy is from a democratic point of view. Ironically, one might say that sense sub-national constitutionalism and sub-national constitutional politics play a similar role as the number " 42 " in Douglas Adams' third book of his science fiction novel "The Hitchhiker's Guide to the Galaxy". In this novel Adams has the computer Deep Thought come up with the "Answer to the Ultimate Question of Life, the Universe, and Everything". As a matter of fact, it took Deep Thought seven and a half million years to compute the answer, which turned out to be: "42" (Adams 2005). 'The problem was that those who designed and switched on Deep Thought failed to ask the proper question. However, if we do not know "The Ultimate Question of Life, the Universe, and Everything", the respective "Answer" is of no use at all - which is a pity, indeed. Subnational constitutionalism seems to share the fate of " 42 " in Adams' novel. For many it is an answer, but we do not know to which question. But we can guess. Overall, we see three discourses in which sub-national constitutional politics plays a crucial role.

Firstly, sub-national constitutions challenge the view that undivided sovereignty is a necessary precondition of an integrated nation-state. On the contrary, in the Federalist Papers Alexander Hamilton, James Madison and John Jay (1778/1994) already rejected the notion that sovereignty has to rest in just one institution. Or: Multilevel systems in general and federalism in particular necessarily break up sovereignty. In this perspective, subnational regions enjoy sovereign prerogatives and can claim to share in statehood. In 
federal states "shared rule" and "self-rule" go together (Elazar 1987; Popelier 2014). The demand for regional self-rule can even lead to secession from a nation-state. Such developments seem to be triggered by processes of globalization and European integration. Indeed, in the EU context every state - federal or not - is part of a multi-level constitutional system. "Methodological nationalism" fails to capture recent changes in member states of the European Union. Unitary states have been transformed into federal states (or they are about to do so), federal states have devolved competences to subnational levels. In other, non-federal EU member states actors at the sub-national level strive for more rights. In some of these cases, sub-national actors got the chance to set up constitutions, establish non-formal statutes, or make over their already existing subnational constitution. Sub-national constitutions become then a means to sustain some sort of autonomy in a multilevel system. In other cases, no formal or explicit constitutional dimension can (yet) be identified, but claims with constitutional relevance are expressed by regional actors (often grounded in distinct minority identities, as in the case of the Hungarian minority in Romania). In yet other cases, tendencies to sub-national constitutionalization are contrasted by or in tension with simultaneous drives to a recentralization of the state (as is currently the case in the constitutional reform in Italy). In this, it remains open to discussion whether sub-national constitutionalism reinforces or contradicts the functioning of the multilevel system. Or, in other words: when do subnational constitutions complement, challenge, or undermine a national or the European political order?

Secondly, the link between sub-national constitutional politics and democracy seems to be as ambivalent as the one between sub-national constitutions, the nation state, and multilevel systems. According to Ernst-Wolfgang Böckenförde, constitutions took different shapes and had different effects throughout history. The Magna Charta Libertatum of 1215 has been a covenant between the British King and his ranks. The Bavarian constitution of 1818 circumscribed royal powers that derived their legitimacy not from the people but from God. The Constitution of the German Confederation of 1815 was an accord between states that transferred sovereign rights to superior institutions but retained their sovereignty (Böckenförde 1992). All these laws had been constitutions in the sense that they organized and set up some sort of government. Contemporary German Land constitutions differ from these historical types for three reasons: They are supposed to be 
superior to other legal acts, they are to set up the polity and the rules for the political process, and they are to be manifestations of the will of the people, hence they have to be democratically legitimized. The claim, then, modern constitutions make is broader. Modern constitutions do not only set up some institutions and organs that help to govern. As a consequence, we can argue that constitutional law and constitutionalism are not the same thing. While the first one refers to formal aspects, the second one tries to accommodate ideas about forms and objectives of the polity. Thus, constitutional law is the most fundamental law of a society. It has to be adopted in a specific way and amended in a more difficult procedure than normal law.

Constitutionalism invokes the idea that these features of constitutional law are not just formal distinctions but represent a specific idea of liberal constitutionalism. Or: Constitutional law serves a substantial - in essence liberal - purpose. It rests on two pillars: on the people's claim for self-governance and on the protection of liberty (Gardner 2007: 2-3). In this view a constitution is a "kind of charter of living". Accordingly, an "ideology of sub-national constitutionalism (...) conceives of state, provincial, or regional constitutions as charters of self-governance self-consciously adopted by subnational populations for the purpose of achieving a good life by effectively ordering subnational governmental power and by protecting the liberties of subnational citizens" (Gardner 2007: 3). In this view, constitutionalism goes together with democratic self-restraint. The demos agrees to limit its sovereign rights in order to protect the liberties of sub-national citizens and guarantee democratic self-rule. However, sub-national constitutions are further circumscribed. In multilevel systems, there is no such thing as constitutional autonomy for sub-national units (Popelier 2014; Lorenz/Reutter 2012). This raises questions about the nature and functions of sub-national constitutions and in what respect these legal texts can set up, improve, and sustain democratic self-rule. At the same time, sub-national or local forms of self-rule might help to re-attach citizens to the democratic process in a context of fragile democratic traditions, the displacement of national sovereignty, and increasing civic adverseness to national politics (Blokker 2012; Lorenz 2013). This relates to a more general trend towards a "democracy of proximity" (Rosanvallon 2011: 171). A democracy of proximity calls for forms of government that are attentive to the needs of citizens, in which an open relationship between the governors and governed exists (accessible and transparent government), and in which the particularity and diversity of context is taken 
into account. In some cases, claims for sub-national autonomy also include an emphasis on a more democratic, inclusive form of engagement with constitutionalism (as to some extent in the Scottish case or in current proposals for a "convention" or "constituent assembly" in Alto-Adige).

Thirdly, with the Maastricht Treaty Europe discovered that member states do have sub-national units. From then onwards, European politicians had to learn what subsidiarity means. Very often subsidiarity is regarded as a sort of synonym for local or sub-national democracy. Many see sub-national units as inherently more democratic and more efficient than national or European entities. Sub-national democracy might work as a partial antidote to efficiency (output legitimation) and legitimacy (input legitimation) problems of European democracies. It can trigger legal innovations and help to clarify the status of such innovative features. However, the link between democracy, constitutional law and subsidiarity is not as straightforward as many seem to assume (Benz 2009; Reutter 2010). Historically, subsidiarity has never been a democratic idea. It is rather a normative rule for allocating competencies between levels. In principle it gives preference to the lower level if - and only if - higher levels are not better in providing the service. In other words subsidiarity just constitutes the need for justification to transfer competencies to higher levels if these are better in dealing with the issue at hand. According to Werner Vandenbruwaene "the commonly shared denominator of the principle of subisidiarity indicates the search for an optimal allocation and exercise of governmental authority in terms of efficiency and legitimacy." (Vandenbruwaene 2014: 49).

\section{2.}

As mentioned above, the special issue collects papers mostly presented at the General Conference the European Consortium of Political Research in Glasgow 2014. The five papers differ in many respects and address divergent issues. Nonetheless, they all observe a strong tendency towards regionalization that is fueled by sub-national constitutional politics.

W. Elliot Bulmer examines an often overlooked aspect in the Scottish attempt for national independence. Bulmer explores how the Scottish strife for national autonomy is linked to constitutional discussions. He brings the roots and traditions of Scottish 
nationalist constitutional thought to the fore. He specifically looks at: (i) selective borrowing from Scandinavian and Commonwealth constitutionalism, whilst simultaneously repudiating, reforming, and replicating, orthodox British constitutional doctrines; (ii) the apparent contrast between radicalism (e.g. the centrality of the idea of popular sovereignty to Scottish nationalist constitutional thought, and the emergence of "ethical constitutionalism", expressed through commitment to values and principles) and "British incrementalism" in terms of specific institutional proposals. It is interesting to look at how - at least since the 2010 and 2011 elections - the Scottish constitutional conversation has diverged from, but continues to be influenced by, the UK-wide constitutional conversation at Westminster.

Ferdinand Karlhofer takes a different stance on the issue at hand He explores a - as it seems: obligatory - fallout of federal systems: the discrepancy between the formal constitution and the informal world of effective politics. Some even see Austria as "federation without federalism" (Karlhofer/Pallaver 2013). While Austria's federal structures are taken as weak or almost as nonexistent, there are strong informal forces at work. As a result, Karlhofer points out, the Austrian federal system suffers from an unclear distribution of rights and duties between the national state and sub-national units. In his paper Karlhofer provides an overview on the characteristics and ambiguities of Austria's federal system and analyzes sub-national constitutional politics. Karlhofer wonders whether the constitutional changes and amendments will pave "the way for a sustainable redesign of the federation as a whole".

Astrid Lorenz addresses the question why sub-national constitutional politics vary with regard to rights of minors. As a matter of fact, it took the EU and Germany a number of years to include the Convention on the Right of the Child 1989 into proper law. It was only in the year 2010 that Germany decided to drop all restriction of any kind and ratify the Convention without qualification. In Germany this triggered some initiatives in the Länder which have important competencies in this field even though cooperative federalism is characterized by homogeneity and centralist policies. Maybe even more importantly, parties and party systems in the Länder pretty much mimic those at the federal level. Yet, in spite of the legal framework, the functioning of cooperative federalism and "unitarian" tendencies in the parties Lorenz identified different policies in the Länder. So, why do parties pursue different strategies in different Länder? Astrid Lorenz' paper seeks to solve 
this puzzle. Lorenz brings to the fore that sub-national constitutional politics in the Länder do not just follow up on developments at the national or European level. On the contrary, Lorenz argues that sub-national constitutional politics can only be explained if we take subnational factors into account. Perceptions, negotiations and procedural rules are subnationally shaped. As a consequence, we have to take these features into account in order to explain sub-national constitutional politics in Germany. And it is only due to these features that sub-national constitutions can help integrating the people into the overall political order. Sub-national constitutional politics does, hence, not challenge the applicability of the federal constitution but rather helps to stabilize the system as a whole by enabling the political actors to find individual constitutional solutions below the level of federal regulation and thus filling integration gaps at the federal level.

Kriszta Kovács, Zsolt Körtvélyesi, and Alíz Nagy tackle the question of how universal human rights that guarantee non-discrimination fit with claims of national sovereignty. As a rule people are born into their political communities. There is no need to apply for citizenship. At the same time nation states are entitled to define the rules of both birthright and acquired political membership. Yet, the authors argue that human rights principles, first and foremost non-discrimination guarantees, should be given preference over national rules. While the arguments presented by Kriszta Kovács, Zsolt Körtvélyesi, and Alíz Nagy are general by nature, they pay special attention to events that pertain to the case of Hungary. The paper explores in this the complex relation between a nationalist constitutional project (Hungary), external minorities (in e.g. Slovakia and Romania), external ethnic citizenship, and the rights and claims to sub-national self-government of Hungarian minorities in bordering countries.

Zubair Shahid addresses similar issues as the preceding papers but in a very different context. Shahid's paper examines the case of Pakistan and how federalism and sub-national self-rule evolved in this developing country and in fragile political circumstances. His paper challenges the widely held view that the tendency to regionalization and multilevel governance is a purely European matter. On the contrary, countries in different world regions and with different political and cultural traditions equally have to deal with these issues.

\footnotetext{
* Paul Blokker is principal investigator (project CoPolis) at the Department of Sociology and Social Research,
} 
University of Trento, Italy, and associate professor at the Institute of Sociological Studies, Charles University, Prague. Werner Reutter is research fellow at the Department of Political Science (University Leipzig); his research is funded by the Deutsche Forschungsgemeinschaft (grant no. GZ: LO 1424/3-1; AOBJ: 604048). ${ }^{\text {I }}$ Cf. also http://en.wikipedia.org/wiki/Phrases from The Hitchhiker's Guide to the Galaxy.

\section{References}

- $\quad$ Adams Douglas, 2005, Life, the Universe and Everything [1982], Del Rey, New York.

- Benz Arthur, 2009, 'Ein gordischer Koten der Politikwssenschaft? Zur Vereinbarkeit von Föderalismus und Demokratie', Politische Vierteljahresschrift, L(1): 3-22.

- Blokker Paul, 2012, 'The Constitutional Premises of Subnational Self-Government in New Democracies', Corvinus Journal of Sociology and Social Policy.

- Böckenförde Ernst-Wolfgang, 1992, 'Geschichtliche Entwicklung und Bedeutungswandel der Verfassung’, in Ernst-Wolfgang Böckenförde, Staat, Verfassung und Demokratie. Studien zur Verfassungstheorie und zum Verfassungsrecht. $2^{\text {nd }}$ edition. Suhrkamp, Frankfurt/Main, 29-52.

- $\quad$ Elazar Daniel J., 1987, Exploring Federalism, The University of Alabama Press, Tuscaloosa.

- Gardner James A., 2007, 'In Search of Sub-National Constitutionalism', Paper prepared for the Seventh World Congress of the International nAssociation of Constitutional Law, Athens, Greece, June 11 15, 2007, available at: http://camlaw.rutgers.edu/statecon/workshop11greece07/workshop11/Gardner.pdf (download: July 10, 2014).

- Hamilton Alexander, Madison James and Jay John, 1994, Die Federalist-Artikel [1788]. Politische Theorie und Verfassungskommentar der amerikanischen Gründungsväter, ed. by Angela Adams and Willi Paul Adams. Schöningh, Paderborn.

- Karlhofer, Ferdinand and Pallaver Günther, 2013, 'Strength through Weakness: State Executive Power and Federal Reform in Austria', Swiss Political Science, XIX(1): 41-59.

- $\quad$ Lorenz Astrid, 2013, Demokratisierung in Ostdeutschland: Verfassungspolitische Weichenstellungen in den neuen Ländern und Berlin, Springer VS, Wiesbaden.

- Lorenz Astrid and Reutter Werner, 2012, 'Subconstitutionalism in a Multilayered System. A Comparative Analysis of Constitutional Politics in the German Länder', Perspectives on Federalism, IV(2): 141170, retrieved from: http://www.on-federalism.eu/attachments/141 download.pdf (download: January 10, 2013).

- $\quad$ Popelier Patricia, 2014, 'Subnational multilevel constitutionalism', Perspectives on Federalism, VI(2): 123, available at http://www.on-federalism.eu/attachments/178 download.pdf (download: November 20, 2014).

- $\quad$ Reutter Werner, 2006, 'The Transfer of Power Hypothesis and the German Länder: In Need of Modification', Publius: The Journal of Federalism, XXXVI(2): 277-301.

- $\quad$ Reutter Werner, 2010, 'Demokratie im Bundesstaat. Zum Verhältnis zweier verfassungsrechtlicher Strukturprinzipien', Zeitschrift für Politikwissenschaft, XX(2): 123-148.

- Reutter Werner 2014, 'Multilevel Systems and Subnational Constitutional Politics in Germany: a Qualitative Comparative Analysis, Perspectives on Federalism, VI(2): 215-243.

- Rosanvallon Pierre, 2011, Democratic legitimacy: Impartiality, reflexivity, proximity, Princeton University Press, Princeton.

- Vandenbruwaene Werner, 2014, 'What Scope for Subnational Autonomy: the Issue oft he Legal Enforcement oft he Prinicple of Subsidiarity', Perspectives on Federalism, VI(2): 45-73.

- Williams Robert. F., 2011: 'Teaching and Researching Comparative Subnational Constitutional Law', Penn State Law Review, CXV(4): 1109-1132. 